\title{
Optimization of medium components using response surface methodology for production of thermostable amylopullulanase in submerged fermentation by Clostridium thermosulfurogenes SVM17
}

\author{
Mrudula, Soma ${ }^{1 *}$, Gopal Reddy ${ }^{2}$ and Seenayya, Gunda ${ }^{3}$ \\ ${ }^{1}$ Department of Microbiology, M. G. R. College, Hosur, T.N, 635 109, India. \\ ${ }^{2}$ Department of Microbiology, Osmania University, Hyderabad, 500 007, A.P, India \\ ${ }^{3}$ R \& D, Issar Pharmaceuticals Pvt. Ltd, Srinagar Colony, Hyderabad, 500 073, A.P, India. \\ E-mail: somamrudula@hotmail.com
}

Received 14 February 2011; received in revised form 7 June 2011; accepted 15 June 2011

\begin{abstract}
Response surface methodology (RSM) based on central composite rotatable design (CCRD) was used to determine the optimal levels of medium components, viz., soluble starch, tapioca flour, peptone, magnesium chloride and ferrous sulphate for enhanced thermostable amylopullulanase production by Clostridium thermosulfurogenes SVM17 in submerged fermentation. The design contains a total of 54 experimental trials with first 32 organized in a fractional factorial design and experimental trials from 33-40 and 51-54 involving the replication of the central points. Within the tested range of concentrations, all medium components were found significant. The optimum levels of nutrients for maximum production of enzyme were $(\% \mathrm{w} / \mathrm{v})$ : potato starch, 5.2; tapioca flour, 6.3; peptone, $2.5 ; \mathrm{MgCl}_{2} \cdot 6 \mathrm{H}_{2} \mathrm{O}, 0.015$ and $\mathrm{FeSO}_{4} \cdot 7 \mathrm{H}_{2} \mathrm{O}, 6.0 \mathrm{ppm}$. After optimization of medium components, the strain SVM17 showed 96 and $409 \%$ increased amylase and pullulanase activities, respectively when compared with the non-optimized conditions.
\end{abstract}

Keywords: Amylase, pullulanase, submerged fermentation, response surface methodology, Clostridium thermosulfurogenes

\section{INTRODUCTION}

Bioprocessing of starch into maltose and maltooligosaccharides by enzymatic means is gaining importance, because of their potential application in food, pharmaceutical, beverage and fine chemical industries (Fogarty and Kelly, 1990; Saha et al., 2009). They are produced by hydrolysis of starch using amylases from higher plants, certain mesophilic bacteria and fungi. The majority of amylases reported so far are optimally active at moderate temperatures (Haki and Rakshit, 2003). Therefore a high value is placed on extreme thermostable enzymes. Presence of both $\alpha-1,4-$ and $\alpha-1,6-$ hydrolyzing enzymes will have added advantages. Thermoanaerobes show promise for production of thermostable enzymes, and efforts have been made to isolate thermoanaerobic bacteria that produce an enzyme which can hydrolyze both $\alpha-1,6$ - linkages in pullulan and starch and $\alpha-1,4-$ linkages in starch. Since the enzymes have both amylase and pullulanase activities, the term amylopullulanase has been coined to categorize them (Saha and Zeikus, 1989; Spreinat and Antranikian, 1990; Kwak et al., 1998; Zareian et al., 2010; Mrudula et al., 2011a; 2011b). Earlier we have isolated anaerobic, thermophilic and amylolytic bacteria in our laboratory (Swamy and Seenayya, 1996a). The strains were further screened for production of maltose and maltooligosaccharides and the strain Clostridium thermosulfurogenes SVM17, which produced increased yield of amylopullulanase and stable at $100{ }^{\circ} \mathrm{C}$ was selected (Mrudula, 2010; Mrudula et al., 2010; Mrudula et al., 2011a; 2011b).

Yield of any microbial product can be improved by optimization of medium components that are required in fermentation processes. Application of statistical methodologies in fermentation process development can result in improved yields of the product, reduced process variability, closer confirmation of the out put response to normal and target requirements, reduced development time with overall costs (Mrudula, 2010). Conventional practice of single variable optimization is, by maintaining other variables involved at a constant level. The major disadvantage of this 'change-single-factor-at-a-time' method is that it does not include interactive effects among the variables (Naidu and Panda, 1999; Jagannadha Rao et al., 2000; Teng and Xu, 2008; Satyanarayana and Pradeep, 2009). This method is a time consuming process and requires a number of experiments to determine optimum levels, which are unreliable and therefore considered to be inferior to statistical methodologies. These limitations of a single factor optimization process can be eliminated by optimizing all the affecting parameters collectively by statistical experimental design using response surface methodology (RSM) (Box and Wilson, 1951; Khuri and Cornell, 1987). RSM has gained importance for optimization of media components and parameters (Uma 
Maheswara Rao and Satyanarayana, 2007; Teng and Xu, 2008; Reddy et al., 2008; Mrudula et al., 2010; Mrudula et al., 2011b). To the best of our knowledge there is no report on optimization of nutrient levels for amylopullulanase using RSM in SmF. In the present study, RSM based on central composite rotatable design (CCRD) was applied to determine the optimum concentrations of medium components for increased production of thermostable amylopullulanase by $C$. thermosulfurogenes SVM17 in SmF.

\section{MATERIALS AND METHODS}

\section{Microorganism and culture conditions}

The bacterial strain used in the present study was isolated in our laboratory and identified as Clostridium thermosulfurogenes SVM17 (Swamy and Seenayya, 1996a; Mrudula, 2010; Mrudula et al., 2011a; Mrudula et al., 2011b). The organism was cultivated anaerobically in $120 \mathrm{~mL}$ serum vials that contained $20 \mathrm{~mL}$ of peptone yeast extract (PYE) medium (Swamy and Seenayya, 1996b).

\section{Submerged fermentation medium and experimental parameters}

Basal medium $(20 \mathrm{~mL})$ containing $(\mathrm{g} / \mathrm{L}) \mathrm{KH}_{2} \mathrm{PO}_{4}, 0.3$; $\mathrm{Na}_{2} \mathrm{HPO}_{4} \cdot 7 \mathrm{H}_{2} \mathrm{O}, 2.0$ and resazurin, 0.002 dissolved in distilled water were dispensed into $120 \mathrm{~mL}$ serum vials. Five medium components, viz., soluble starch (0.5-6.5\%), tapioca flour (0.5-6.5\%), peptone (1.5-3.5\%), $\mathrm{MgCl}_{2} \cdot 6 \mathrm{H}_{2} \mathrm{O}$ $(0.005-0.025 \%)$ and $\mathrm{FeSO}_{4} \cdot 7 \mathrm{H}_{2} \mathrm{O}(2.0-10.0 \mathrm{ppm})$ with 3.5 , $3.5,2.5,0.015$ and $6.0 \mathrm{ppm}$, respectively as their central points under study were added to each vial as given in RSM experimental design (Table 1). The concentration range for each nutrient was fixed based on the literature (Rama Mohan Reddy et al., 2003) and on our own experience gained. The medium was flushed with nitrogen gas to create anaerobic conditions and vials were sealed and sterilized at $121^{\circ} \mathrm{C}$ for $15 \mathrm{~min}$. The vials were cooled to r.t. $\left(28 \pm 2{ }^{\circ} \mathrm{C}\right.$ and $2 \%(\mathrm{v} / \mathrm{v})$ of $2.5 \%(\mathrm{w} / \mathrm{v}) \mathrm{Na}_{2} \mathrm{~S}$ was added, $\mathrm{pH}$ was adjusted to 7.5 , inoculated with $5 \%(\mathrm{v} / \mathrm{v})$ exponentially grown culture and incubated at $60{ }^{\circ} \mathrm{C}$ for 24 h.

\section{Experimental design}

A central composite rotatable design (CCRD) was used to optimize the concentrations of nutrients. The design contains a total of 54 experimental trials with first 32 organized in a fractional factorial design (Cochran and Cox, 1957; Rama Mohan Reddy et al., 2003; Mrudula, 2010), the experimental trials from 33-40 and 51-54 involve the replications of central points and experimental trials from 41-50 are axial points (star points). The response i.e., amount of enzyme produced by $C$. thermosulfurogenes SVM17 was assumed to be influenced by the five factors selected for the study. Once the experiments were performed, the coefficients of second-order polynomial model for five factors were calculated from the following equation (Montgomery, 1991).

$Y=b_{0}+b_{1} X_{1}+b_{2} X_{2}+b_{3} X_{3}+b_{4} X_{4}+b_{5} X_{5}+b_{11} X_{1}^{2}+b_{22}$ $X_{2}^{2}+b_{33} X_{3}^{2}+b_{44} X_{4}^{2}+b_{55} X_{5}^{2}+b_{12} X_{1} X_{2}+b_{13} X_{1} X_{3}+$ $b_{14} X_{1} X_{4}+b_{15} X_{1} X_{5}+b_{23} X_{2} X_{3}+b_{24} X_{2} X_{4}+b_{25} X_{2} X_{5}+$ $b_{34} X_{3} X_{4}+b_{35} X_{3} X_{5}+b_{45} X_{4} X_{5}+B$

Where, $y$ is the response (predicted yield of enzyme), $b_{0}$ is the intercept, $b_{1}, b_{2}, b_{3}, b_{4}$ and $b_{5}$ are the linear coefficients, $b_{11}, b_{22}, b_{33}, b_{44}$ and $b_{55}$ are quadratic coefficients and $b_{12}-15, b_{23-25}, b_{34-35}$ and $b_{45}$ are the interactive coefficients.

Significance of the model was determined based on lack of fit and significance of each coefficient was determined using the student $t$-test (Gong and Chen, 1998; Rama Mohan Reddy et al., 2000; Mrudula 2010). Graphical representation of these equations are called response surface curves, used to describe the individual and cumulative effect of the test variable (factor) on the response and to determine the mutual interactions between two test variables and their subsequent effect on the response (Khuri and Cornell, 1987; Montgomery, 1991). The three dimensional response surface plot was drawn with vertical axis representing the enzyme yield and two horizontal axes representing five different levels of two explanatory nutrients by keeping other three factors at zero level.

The results were analyzed using the 'Indostat' statistical software (Indostat services, Hyderabad, India; Anonymous, 1998). Optimum concentration of each nutrient is identified based on the hump in three dimensional plots.

\section{Enzyme assay}

Amylase and pullulanase activities were measured by incubating $0.5 \mathrm{ml}$ of appropriately diluted enzyme source with $0.5 \mathrm{ml}$ of $1 \%(\mathrm{w} / \mathrm{v})$ starch solution and pullulan solution, respectively in $2 \mathrm{~mL}$ of $0.1 \mathrm{M}$ acetate buffer $(\mathrm{pH}$ 5.5) at $70{ }^{\circ} \mathrm{C}$ for 30 min respectively. After incubation, reaction was stopped by cooling the tubes in an ice bath. The reducing sugars released by enzymatic hydrolysis of soluble starch and pullulan were determined by addition of $1 \mathrm{~mL}$ of 3,5-dinitrosalicylic acid (Miller, 1959). A separate blank was set up for each sample to correct the nonenzymatic release of sugars. One unit of amylase or pullulanase is defined as the rate of formation of $(1 \mathrm{U} \mathrm{mol})$ of reducing sugars (as glucose equivalents) per min under standard assay conditions.

\section{RESULTS AND DISCUSSION}

C. thermosulfurogenes SVM17 grew optimally at growth temperature of $60^{\circ} \mathrm{C}$, at an initial $\mathrm{pH}$ of 7.5 and incubation period of $24 \mathrm{~h}$. Under these conditions, the strain produced 2600 and $1300 \mathrm{U}$ of thermostable amylase and pullulanase activities, respectively per litre of culture broth 
using PYE medium containing $0.5 \%(\mathrm{w} / \mathrm{v})$ soluble starch as carbon source.

Previously 15 nutrients comprising of four each of carbon, nitrogen, minerals and then complex organic sources (flours) were screened using Plackett-Burman design for thermostable amylopullulanase production by $C$. thermosulfurogens SVM17 in SmF (Mrudula et al., 2010). Among them five medium components, viz., starch, tapioca flour, peptone, $\mathrm{MgCl}_{2}$ and $\mathrm{FeSO}_{4}$ have been identified as most significant and further selected for optimization of their levels using RSM in SmF.

Table 1: Central composite rotatable design (CCRD) of five medium components in coded and uncoded units: Effect of each combination on the production of thermostable amylopullulanase by $C$. thermosulfurogenes SVM17 in SmF.

\begin{tabular}{|c|c|c|c|c|c|}
\hline $\begin{array}{l}\text { Combination } \\
\text { number }\end{array}$ & $\begin{array}{l}\text { Soluble starch } \\
\%(\mathrm{w} / \mathrm{v}) \\
\mathrm{X}_{1}\end{array}$ & $\begin{array}{l}\text { Tapioca flour } \\
\%(\mathrm{w} / \mathrm{v}) \\
\mathrm{X}_{2}\end{array}$ & $\begin{array}{l}\text { Peptone } \\
\%(\mathrm{w} / \mathrm{v}) \\
\mathrm{X}_{3}\end{array}$ & $\begin{array}{l}\mathrm{MgCl}_{2} \cdot 6 \mathrm{H}_{2} \mathrm{O} \\
\%(\mathrm{w} / \mathrm{v}) \\
\mathrm{X}_{4}\end{array}$ & $\begin{array}{l}\mathrm{FeSO}_{4} \cdot 7 \mathrm{H}_{2} \mathrm{O} \\
\text { ppm } \\
\mathrm{X}_{5} \\
\end{array}$ \\
\hline 1 & $-1(2.0)$ & $-1(2.0)$ & $-1(2.0)$ & $-1(0.01)$ & $-1(4.0)$ \\
\hline 2 & $1(5.0)^{\prime}$ & $-1(2.0)$ & $-1(2.0)$ & $-1(0.01)$ & $-1(4.0)$ \\
\hline 3 & $-1(2.0)$ & $1(5.0)$ & $-1(2.0)$ & $-1(0.01)$ & $-1(4.0)$ \\
\hline 4 & $1(5.0)$ & $1(5.0)$ & $-1(2.0)$ & $-1(0.01)$ & $-1(4.0)$ \\
\hline 5 & $-1(2.0)$ & $-1(2.0)$ & $1(3.0)$ & $-1(0.01)$ & $-1(4.0)$ \\
\hline 6 & $1(5.0)$ & $-1(2.0)$ & $1(3.0)$ & $-1(0.01)$ & $-1(4.0)$ \\
\hline 7 & $-1(2.0)$ & $1(5.0)$ & $1(3.0)$ & $-1(0.01)$ & $-1(4.0)$ \\
\hline 8 & $1(5.0)$ & $1(5.0)$ & $1(3.0)$ & $-1(0.01)$ & $-1(4.0)$ \\
\hline 9 & $-1(2.0)$ & $-1(2.0)$ & $-1(2.0)$ & $1(0.02)$ & $-1(4.0)$ \\
\hline 10 & $1(5.0)$ & $-1(2.0)$ & $-1(2.0)$ & $1(0.02)$ & $-1(4.0)$ \\
\hline 11 & $-1(2.0)$ & $1(5.0)$ & $-1(2.0)$ & $1(0.02)$ & $-1(4.0)$ \\
\hline 12 & $1(5.0)$ & $1(5.0)$ & $-1(2.0)$ & $1(0.02)$ & $-1(4.0)$ \\
\hline 13 & $-1(2.0)$ & $-1(2.0)$ & $1(3.0)$ & $1(0.02)$ & $-1(4.0)$ \\
\hline 14 & $1(5.0)$ & $-1(2.0)$ & $1(3.0)$ & $1(0.02)$ & $-1(4.0)$ \\
\hline 15 & $-1(2.0)$ & $1(5.0)$ & $1(3.0)$ & $1(0.02)$ & $-1(4.0)$ \\
\hline 16 & $1(5.0)$ & $1(5.0)$ & $1(3.0)$ & $1(0.02)$ & $-1(4.0)$ \\
\hline 17 & $-1(2.0)$ & $-1(2.0)$ & $-1(2.0)$ & $-1(0.01)$ & $1(8.0)$ \\
\hline 18 & $1(5.0)$ & $-1(2.0)$ & $-1(2.0)$ & $-1(0.01)$ & $1(8.0)$ \\
\hline 19 & $-1(2.0)$ & $1(5.0)$ & $-1(2.0)$ & $-1(0.01)$ & $1(8.0)$ \\
\hline 20 & $1(5.0)$ & $1(5.0)$ & $-1(2.0)$ & $-1(0.01)$ & $1(8.0)$ \\
\hline 21 & $-1(2.0)$ & $-1(2.0)$ & $1(3.0)$ & $-1(0.01)$ & $1(8.0)$ \\
\hline 22 & $1(5.0)$ & $-1(2.0)$ & $1(3.0)$ & $-1(0.01)$ & $1(8.0)$ \\
\hline 23 & $-1(2.0)$ & $1(5.0)$ & $1(3.0)$ & $-1(0.01)$ & $1(8.0)$ \\
\hline 24 & $1(5.0)$ & $1(5.0)$ & $1(3.0)$ & $-1(0.01)$ & $1(8.0)$ \\
\hline 25 & $-1(2.0)$ & $-1(2.0)$ & $-1(2.0)$ & $1(0.02)$ & $1(8.0)$ \\
\hline 26 & $1(5.0)$ & $-1(2.0)$ & $-1(2.0)$ & $1(0.02)$ & $1(8.0)$ \\
\hline 27 & $-1(2.0)$ & $1(5.0)$ & $-1(2.0)$ & $1(0.02)$ & $1(8.0)$ \\
\hline 28 & $1(5.0)$ & $1(5.0)$ & $-1(2.0)$ & $1(0.02)$ & $1(8.0)$ \\
\hline 29 & $-1(2.0)$ & $-1(2.0)$ & $1(3.0)$ & $1(0.02)$ & $1(8.0)$ \\
\hline 30 & $1(5.0)$ & $-1(2.0)$ & $1(3.0)$ & $1(0.02)$ & $1(8.0)$ \\
\hline 31 & $-1(2.0)$ & $1(5.0)$ & $1(3.0)$ & $1(0.02)$ & $1(8.0)$ \\
\hline 32 & $1(5.0)$ & $1(5.0)$ & $1(3.0)$ & $1(0.02)$ & $1(8.0)$ \\
\hline 33 & $0(3.5)$ & $0(3.5)$ & $0(2.5)$ & $0(0.015)$ & $0(6.0)$ \\
\hline 34 & $0(3.5)$ & $0(3.5)$ & $0(2.5)$ & $0(0.015)$ & $0(6.0)$ \\
\hline 35 & $0(3.5)$ & $0(3.5)$ & $0(2.5)$ & $0(0.015)$ & $0(6.0)$ \\
\hline 36 & $0(3.5)$ & $0(3.5)$ & $0(2.5)$ & $0(0.015)$ & $0(6.0)$ \\
\hline 37 & $0(3.5)$ & $0(3.5)$ & $0(2.5)$ & $0(0.015)$ & $0(6.0)$ \\
\hline 38 & $0(3.5)$ & $0(3.5)$ & $0(2.5)$ & $0(0.015)$ & $0(6.0)$ \\
\hline 39 & $0(3.5)$ & $0(3.5)$ & $0(2.5)$ & $0(0.015)$ & $0(6.0)$ \\
\hline 40 & $0(3.5)$ & $0(3.5)$ & $0(2.5)$ & $0(0.015)$ & $0(6.0)$ \\
\hline 41 & $-2(0.5)$ & $0(3.5)$ & $0(2.5)$ & $0(0.015)$ & $0(6.0)$ \\
\hline 42 & $2(6.5)$ & $0(3.5)$ & $0(2.5)$ & $0(0.015)$ & $0(6.0)$ \\
\hline 43 & $0(3.5)$ & $-2(0.5)$ & $0(2.5)$ & $0(0.015)$ & $0(6.0)$ \\
\hline 44 & $0(3.5)$ & $2(6.5)$ & $0(2.5)$ & $0(0.015)$ & $0(6.0)$ \\
\hline
\end{tabular}




\begin{tabular}{llllll}
45 & $0(3.5)$ & $0(3.5)$ & $-2(1.5)$ & $0(0.015)$ & $0(6.0)$ \\
46 & $0(3.5)$ & $0(3.5)$ & $2(3.5)$ & $0(0.015)$ & $0(6.0)$ \\
47 & $0(3.5)$ & $0(3.5)$ & $0(2.5)$ & $-2(0.005)$ & $0(6.0)$ \\
48 & $0(3.5)$ & $0(3.5)$ & $0(2.5)$ & $2(0.025)$ & $0(6.0)$ \\
49 & $0(3.5)$ & $0(3.5)$ & $0(2.5)$ & $0(0.015)$ & $-2(2.0)$ \\
50 & $0(3.5)$ & $0(3.5)$ & $0(2.5)$ & $0(0.015)$ & $2(10.0)$ \\
51 & $0(3.5)$ & $0(3.5)$ & $0(2.5)$ & $0(0.015)$ & $0(6.0)$ \\
52 & $0(3.5)$ & $0(3.5)$ & $0(2.5)$ & $0(0.015)$ & $0(6.0)$ \\
53 & $0(3.5)$ & $0(3.5)$ & $0(2.5)$ & $0(0.015)$ & $0(6.0)$ \\
54 & $0(3.5)$ & $0(3.5)$ & $0(2.5)$ & $0(0.015)$ & $0(6.0)$ \\
\hline
\end{tabular}

\section{Response surface analysis for the optimization of nutrient levels}

The predicted and experimental yields of pullulanase and amylase for 54 experiments are given in Table 2. The regression coefficients and $t$-values of pullulanase and amylase are given in Tables 3 and 4, respectively. Analysis of variance (ANOVA) is required to test the significance and adequacy of the model. From Tables 3 and 4, ANOVA of the model demonstrates that the model is highly significant, as is evident from Fisher, $F$-test ( $F$ model, mean square regression/mean square residual) and a very low probability value. The $F$ values corresponding to pullulanase and amylase are 4.702 and 4.457, respectively and $P$ values of the models were less than 0.00005 and 0.00008 for pullulanase and amylase respectively. Greater the $F$ value is from one, the more certain that the factors explain adequately the variation in the data about its mean and the estimated factor effects are real. $P$ values were used as a tool to check the significance of each of the coefficient which in turn was necessary to understand the pattern of the mutual interactions between the test variables. Smaller the magnitude of $P$, more significant is the corresponding coefficient (Khuri and Cornell, 1987). Goodness of the model was checked by the co-efficient of determination, $R^{2}$. Closer the values of $R$ (multiple correlation coefficients) to 1 , better the correlation between observed and predicted values. Hence we observed the values of $\mathrm{R}$ for pullulanase (0.870) and amylase (0.864) indicate a good agreement between the experimental and predicted values of pullulanase and amylase yields, respectively. The $\mathrm{R}^{2}$ for pullulanase and amylase were 0.757 and 0.746 , respectively. Coefficient of variation (CV) indicates the degree of precision with which the treatments are compared. Usually, higher the value of $\mathrm{CV}$, lower is the reliability of experiments performed. Here a lower value of CV (9.56 for pullulanase and 9.92 for amylase) indicates a greater reliability of the experiments performed.

The regression coefficients and corresponding $P$ values (Tables 3 and 4 ) suggest that, among the test variables, linear relationship between soluble starch and enzyme yields and tapioca flour and enzyme yields were highly significant followed by both linear and quadratic relations between peptone and enzyme yields. Ferrous sulphate also influences the enzyme yields but its quadratic effect was more pronounced than the linear effect. The mutual interaction between tapioca flour and magnesium chloride is also important and other interactions are insignificant.

\section{Interactions among the nutrients}

Figures $1 a, b$ to $5 a, b$ are the significant response surface curves for amylase and pullulanase activities of thermostable amylopullulanase, respectively as a function of concentrations of two medium components with other three components held at zero level. From the response surface plots, it is easy and convenient to understand the interactions between two nutrients and also to locate their optimum levels.

From Figures $1 \mathrm{a}, \mathrm{b}$, it can be seen that the yields of both amylase and pullulanase were increased as the concentration of soluble starch increased from 0.5 to $6.5 \%$. Similarly the enzyme yields were increased up on increasing the concentrations of tapioca flour from 0.5 to $5.0 \%$ (Figures $2 \mathrm{a}, \mathrm{b}$ ) at higher concentrations of peptone (Figures 2a, b). High concentration of magnesium chloride is required for maximum production of enzymes in the presence of high concentrations of peptone (2.5-3.0\%) (Figures $4 \mathrm{a}, \mathrm{b})$ and ferrous sulphate $(8.0 \mathrm{ppm})$ (Figures $5 a, b)$. High enzyme yields of amylase and pullulanase were recorded when ferrous sulphate was used at a concentration of 8.0 ppm (Figures $3 \mathrm{a}, \mathrm{b}$ ).

From the above observations, it is clear that the maximum pullulanase and amylase activities were observed when the concentrations of test variables lie in the following ranges (\% w/v): soluble starch 5-6.5; tapioca flour, 5.0; peptone, 2.5-3.0; ferrous sulphate, 7.0-8.0 ppm and magnesium chloride, 0.015-0.02. Based on the above observations, the model predicted optimum levels of nutrients for maximum production of enzyme were $(\% \mathrm{w} / \mathrm{v})$ : potato starch, 5.2; tapioca flour, 6.3; peptone, 2.5; magnesium chloride, 0.015 and ferrous sulphate, $6.0 \mathrm{ppm}$. By substituting the corresponding coded concentration levels of factors into the regression equation, maximum predictable response for amylase and pullulanase activities were calculated. Maximum yield of amylase and pullulanase obtained using the optimized medium was 5,099 and $6,610 \mathrm{U} / \mathrm{L}$, respectively. It was in correlation with the predicted yields. After optimization, the yields of amylase and pullulanase were increased by 96 and $409 \%$, respectively. 
Table 2: Experimental and predicted pullulanase and amylase activities of thermostable amylopullulanase produced by C. thermosulfurogenes SVM17 in submerged fermentation.

\begin{tabular}{|c|c|c|c|c|c|c|}
\hline \multirow[b]{2}{*}{ C.No* } & \multicolumn{3}{|c|}{ Pullulanase activity (U/L) } & \multicolumn{3}{|c|}{ Amylase activity (U/L) } \\
\hline & $\begin{array}{c}\text { Experimental } \\
\text { yield }\end{array}$ & $\begin{array}{l}\text { Predicted } \\
\text { yield }\end{array}$ & Residual & $\begin{array}{c}\text { Experimental } \\
\text { yield }\end{array}$ & $\begin{array}{l}\text { Predicted } \\
\text { yield }\end{array}$ & Residual \\
\hline 1 & 3,663 & 3,654 & 9 & 3,019 & 2,995 & 24 \\
\hline 2 & 5,167 & 4,970 & 198 & 4,341 & 4,159 & 182 \\
\hline 3 & 5,269 & 4,499 & 770 & 4,316 & 3,661 & 655 \\
\hline 4 & 5,644 & 5,526 & 118 & 4,740 & 4,605 & 135 \\
\hline 5 & 4,338 & 4,373 & -35 & 3,552 & 3,621 & -69 \\
\hline 6 & 5,413 & 5,311 & 102 & 4,547 & 4,550 & -3 \\
\hline 7 & 4,628 & 4,762 & -134 & 3,791 & 3,885 & -94 \\
\hline 8 & 4,912 & 5,412 & -500 & 4,126 & 4,594 & -468 \\
\hline 9 & 3,480 & 3,582 & -102 & 2,923 & 2,996 & -73 \\
\hline 10 & 3,995 & 4,536 & -541 & 3,356 & 3,802 & -446 \\
\hline 11 & 5,185 & 5,107 & 78 & 4,246 & 4,283 & -37 \\
\hline 12 & 6,321 & 5,773 & 548 & 5,334 & 4,869 & 465 \\
\hline 13 & 4,971 & 4,450 & 521 & 4,071 & 3,658 & 413 \\
\hline 14 & 5,623 & 5,027 & 596 & 4,723 & 4,229 & 494 \\
\hline 15 & 5,080 & 5,519 & -439 & 4,160 & 4,543 & -383 \\
\hline 16 & 6,041 & 5,809 & 233 & 5,227 & 4,894 & 333 \\
\hline 17 & 4,082 & 3,897 & 185 & 3,342 & 3,284 & 58 \\
\hline 18 & 5,802 & 5,307 & 495 & 4,873 & 4,419 & 454 \\
\hline 19 & 3,207 & 4,414 & -1207 & 2,693 & 3,727 & -1034 \\
\hline 20 & 5,227 & 5,536 & -309 & 4,390 & 4,642 & -252 \\
\hline 21 & 4,463 & 5,066 & -603 & 3,655 & 4,205 & -550 \\
\hline 22 & 5,679 & 6,100 & -421 & 4,848 & 5,105 & -257 \\
\hline 23 & 5,993 & 5,128 & 865 & 5,011 & 4,246 & 765 \\
\hline 24 & 6,123 & 5,872 & 251 & 5,143 & 4,926 & 217 \\
\hline 25 & 3,871 & 3,513 & 358 & 3,432 & 3,101 & 331 \\
\hline 26 & 4,441 & 4,563 & -122 & 3,730 & 3,878 & -148 \\
\hline 27 & 5,020 & 4,711 & 309 & 4,537 & 4,165 & 372 \\
\hline 28 & 5,570 & 5,472 & 98 & 4,884 & 4,722 & 162 \\
\hline 29 & 4,569 & 4,832 & -263 & 3,838 & 4,059 & -221 \\
\hline 30 & 5,352 & 5,505 & -153 & 4,495 & 4,601 & -106 \\
\hline 31 & 5,328 & 5,574 & -246 & 4,475 & 4,720 & -245 \\
\hline 32 & 5,600 & 5,958 & -358 & 4,704 & 5,043 & -339 \\
\hline 33 & 5,826 & 5,775 & 51 & 4,893 & 4,862 & 32 \\
\hline 34 & 5,882 & 5,775 & 107 & 4,940 & 4,862 & 79 \\
\hline 35 & 6,187 & 5,775 & 412 & 5,198 & 4,862 & 337 \\
\hline 36 & 5,453 & 5,775 & -322 & 4,580 & 4,862 & -282 \\
\hline 37 & 5,338 & 5,775 & -437 & 4,484 & 4,862 & -338 \\
\hline 38 & 5,515 & 5,775 & -260 & 4,633 & 4,862 & -229 \\
\hline 39 & 5,862 & 5,775 & 87 & 4,925 & 4,862 & 64 \\
\hline 40 & 5,834 & 5,775 & 59 & 4,900 & 4,862 & 39 \\
\hline 41 & 4,391 & 4,386 & 5 & 3,688 & 3,602 & 86 \\
\hline 42 & 6,006 & 6,086 & -80 & 4,918 & 5,088 & -170 \\
\hline 43 & 4,779 & 4,853 & -74 & 4,014 & 4,014 & 0 \\
\hline 44 & 6,151 & 6,152 & -1 & 5,037 & 5,122 & -85 \\
\hline 45 & 3,588 & 3,993 & -405 & 3,015 & 3,398 & -383 \\
\hline 46 & 5,527 & 5,197 & 330 & 4,642 & 4,344 & 298 \\
\hline 47 & 5,408 & 5,263 & 145 & 4,429 & 4,269 & 160 \\
\hline 48 & 5,056 & 5,276 & -220 & 4,141 & 4,386 & -245 \\
\hline 49 & 4,193 & 4,866 & -673 & 3,522 & 4,045 & -523 \\
\hline 50 & 5,857 & 5,259 & 598 & 4,920 & 4,482 & 438 \\
\hline
\end{tabular}


Mal. J. Microbiol. Vol 7(4) 2011, pp. 181-191

\begin{tabular}{llccccc}
51 & 5,878 & 5,759 & 119 & 4,937 & 4,810 & 127 \\
52 & 5,785 & 5,759 & 26 & 4,859 & 4,810 & 49 \\
53 & 5,849 & 5,759 & 90 & 4,913 & 4,810 & 103 \\
54 & 5,898 & 5,759 & 139 & 4,954 & 4,810 & 144 \\
\hline
\end{tabular}

${ }^{*}$ Combination number

Experiments were conducted in $120 \mathrm{~mL}$ serum vials with respective concentrations of nutrients as per the design (Table 1) along with $\mathrm{KH}_{2} \mathrm{PO}_{4}(0.3 \mathrm{~g} / \mathrm{L})$ and $\mathrm{Na}_{2} \mathrm{HPO}_{4}(2.0 \mathrm{~g} / \mathrm{L})$ dissolved in distilled water incubated at $60{ }^{\circ} \mathrm{C}$ for $24 \mathrm{~h}$. The enzyme activities were assayed under standard assay conditions.

Table 3: Significance of regression coefficients of pullulanase activity (in SmF) model ${ }^{\mathrm{a}}$.

\begin{tabular}{|c|c|c|c|}
\hline $\begin{array}{l}\text { Process } \\
\text { variable }\end{array}$ & $\begin{array}{c}\text { Regression } \\
\text { coefficient }\end{array}$ & $\begin{array}{c}\text { Computed } \\
\text { t-value }\end{array}$ & $\begin{array}{c}\text { Significance } \\
\text { level }\end{array}$ \\
\hline INTERCEPT & 5790.38 & 21.30 & \\
\hline $\begin{array}{l}X_{1} \text { soluble } \\
\text { starch }\end{array}$ & 424.83 & 5.41 & $* * *$ \\
\hline $\begin{array}{l}\mathrm{X}_{2} \text { tapioca } \\
\text { flour }\end{array}$ & 324.58 & 4.13 & $* * *$ \\
\hline$X_{3}$ peptone & 301.18 & 3.83 & $* * *$ \\
\hline $\begin{array}{l}\mathrm{X}_{4} \mathrm{MgCl}_{2} . \\
6 \mathrm{H}_{2} \mathrm{O}\end{array}$ & 3.33 & 0.04 & \\
\hline $\begin{array}{l}\mathrm{X}_{5} \mathrm{FeSO}_{4} . \\
7 \mathrm{H}_{2} \mathrm{O}\end{array}$ & 98.13 & 1.25 & \\
\hline$x_{1}^{2}$ & -130.71 & -1.52 & \\
\hline $\mathrm{X}_{2}^{2}$ & -64.09 & -0.75 & \\
\hline$x_{3}^{2}$ & -290.96 & -3.39 & $* * *$ \\
\hline$X_{4}^{2}$ & -122.34 & -1.43 & \\
\hline$X_{5}^{2}$ & -174.09 & -2.03 & * \\
\hline$X_{1} X_{2}$ & -72.09 & -0.82 & \\
\hline$X_{1} X_{3}$ & -94.28 & -1.07 & \\
\hline$X_{1} X_{4}$ & -90.16 & -1.02 & \\
\hline$X_{1} X_{5}$ & 23.72 & 0.27 & \\
\hline $\mathrm{X}_{2} \mathrm{X}_{3}$ & -113.90 & -1.30 & \\
\hline $\mathrm{X}_{2} \mathrm{X}_{4}$ & 170.22 & 1.94 & * \\
\hline $\mathrm{X}_{2} \mathrm{X}_{5}$ & -81.91 & -0.93 & \\
\hline$X_{3} X_{4}$ & 37.28 & 0.43 & \\
\hline$X_{3} X_{5}$ & 112.65 & 1.2 & \\
\hline$X_{4} X_{5}$ & -77.72 & -0.89 & \\
\hline Block & -15.77 & -0.10 & \\
\hline
\end{tabular}

Table 4: Significance of regression coefficients of amylase activity (in $\mathrm{SmF}$ ) model ${ }^{\mathrm{a}}$.

\begin{tabular}{|c|c|c|c|}
\hline $\begin{array}{l}\text { Process } \\
\text { variable }\end{array}$ & $\begin{array}{l}\text { Regression } \\
\text { coefficient }\end{array}$ & $\begin{array}{l}\text { Computed } \\
\text { t-value }\end{array}$ & $\begin{array}{c}\text { Significance } \\
\text { level }\end{array}$ \\
\hline INTERCEPT & 4913.40 & 20.78 & \\
\hline $\begin{array}{l}\mathrm{X}_{1} \text { soluble } \\
\text { starch }\end{array}$ & 371.50 & 5.44 & $* * *$ \\
\hline $\begin{array}{l}X_{2} \text { tapioca } \\
\text { flour }\end{array}$ & 276.95 & 4.06 & $* * *$ \\
\hline$X_{3}$ peptone & 236.60 & 3.47 & *** \\
\hline $\begin{array}{l}\mathrm{X}_{4} \mathrm{MgCl}_{2} . \\
6 \mathrm{H}_{2} \mathrm{O}\end{array}$ & 29.30 & 0.43 & \\
\hline $\begin{array}{l}\mathrm{X}_{5} \mathrm{FeSO}_{4} . \\
7 \mathrm{H}_{2} \mathrm{O}\end{array}$ & 109.35 & 1.60 & \\
\hline$x_{1}^{2}$ & -116.07 & -1.56 & \\
\hline$X_{2}^{2}$ & -60.44 & -0.81 & \\
\hline$x_{3}^{2}$ & -234.69 & -3.15 & $* * *$ \\
\hline$X_{4}^{2}$ & -120.57 & -1.62 & \\
\hline$X_{5}{ }^{2}$ & -136.57 & -1.83 & * \\
\hline $\mathrm{X}_{1} \mathrm{X}_{2}$ & -55.06 & -0.72 & \\
\hline $\mathrm{X}_{1} \mathrm{X}_{3}$ & -58.75 & -0.77 & \\
\hline $\mathrm{X}_{1} \mathrm{X}_{4}$ & -89.31 & -1.17 & \\
\hline$X_{1} X_{5}$ & -7.25 & -0.09 & \\
\hline $\mathrm{X}_{2} \mathrm{X}_{3}$ & -100.50 & -1.32 & \\
\hline $\mathrm{X}_{2} \mathrm{X}_{4}$ & 155.19 & 2.03 & * \\
\hline$X_{2} X_{5}$ & -55.75 & -0.73 & \\
\hline $\mathrm{X}_{3} \mathrm{X}_{4}$ & 9.13 & 0.12 & \\
\hline$X_{3} X_{5}$ & 73.94 & 0.97 & \\
\hline $\mathrm{X}_{4} \mathrm{X}_{5}$ & -45.89 & -0.60 & \\
\hline Block & -51.85 & -0.38 & \\
\hline
\end{tabular}

a: Significance levels of regression coefficients are given as $* * *$ $99.9 \%,{ }^{* *} 99.0 \%$ and ${ }^{*} 95.0$ by $t$-test: " $F$ ratio" for the model was 4.457 degrees of freedom were 21,32 ). Probably $=0.00008, R^{2}=$ 0.7573 and $R^{2}=$ adjusted $=0.57989$ 
Several reports are available in literature on statistical approaches (such as RSM) for optimization of medium components and various physical parameters for production of different microbial products. In SmF, the RSM has been applied for production of $\alpha$-amylase by Bacillus sp. (Tanyildizi et al., 2005), Geobacillus thermoleovorans (Uma Maheswara Rao and Satyanarayana, 2007), lipase by Geotrichum sp. (Burkert et al., 2004), whole cell lipase by Rhizopus chinensis (Teng and $\mathrm{Xu}, 2008$ ), phytase by $E$. coli (Sunitha et al., 1999), glucosyl transferase by Aspergillus niger (Lee and Chen, 1997), laccase by Botryosphaeria sp. (Vasconcelos et al., 2000). A two fold increase in $\alpha$-amylase production was reported in B. circulans GRS313 (Dey et al., 2002) by use of response surface methodology. Rama Mohan Reddy et al., (1999; 2003) reported about 10 and 36\% more pullulanase and $\beta$-amylase by Clostridium thermosulfurogens SV2 after optimization of medium composition. Amylopullulanase of Clostridium thermosulfurogens SVM 17 showed increase in the yields of amylase and pullulanase by $106 \%$ and $182 \%$, respectively in SSF (Mrudula, 2010).

Kapat et al. (1998) used RSM to evaluate optimum environmental conditions for production of glucose oxidase. With these optimized physical parameters, glucose oxidase production by recombinant $S$. cerevisiae was increased by $74 \%$ compared to un-optimized conditions.

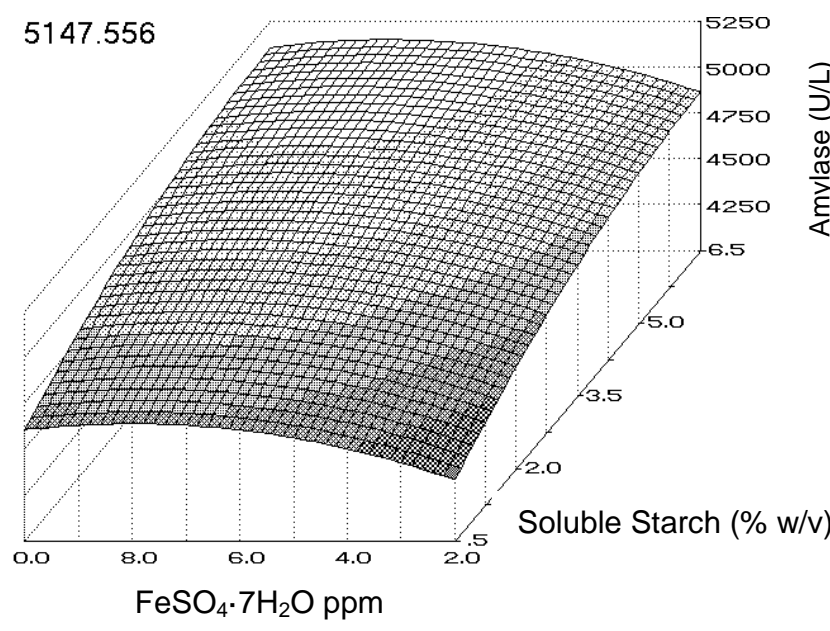

Figure 1a: Response surface plot for the production of thermostable amylopullulanase by $C$. thermosulfurogenes SVM 17 in SmF as a function of varying concentrations of soluble starch and $\mathrm{FeSO}_{4} .7 \mathrm{H}_{2} \mathrm{O}$ on the yield of amylase when the tapioca flour $(3.5 \% \mathrm{w} / \mathrm{v})$, peptone $(2.5 \% \mathrm{w} / \mathrm{v})$ and $\mathrm{MgCl}_{2} \cdot 6 \mathrm{H}_{2} \mathrm{O}(0.015 \% \mathrm{w} / \mathrm{v})$ were held at zero level.

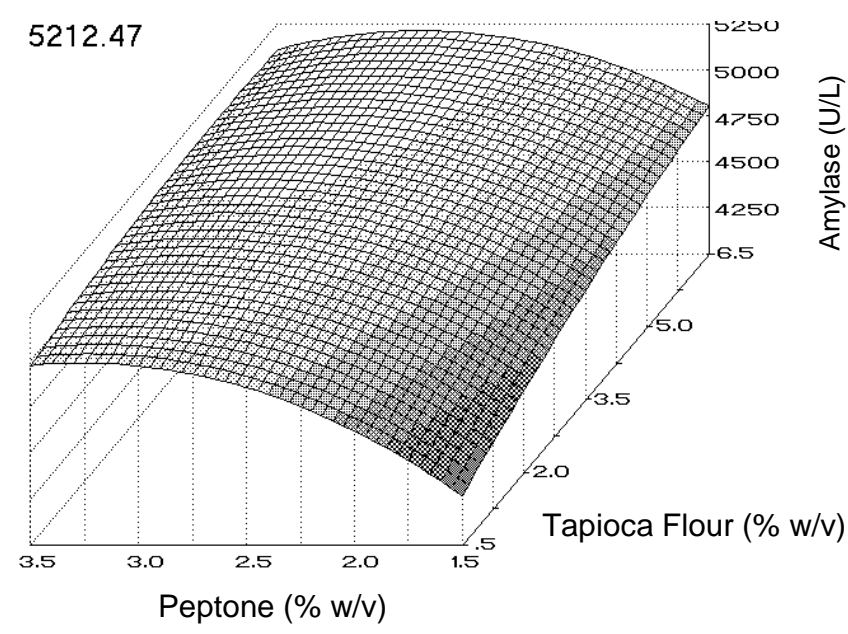

Figure 2a: Response surface plot for the production of thermostable amylopullulanase by $C$. thermosulfurogenes SVM 17 in SmF as a function of varying concentrations of tapioca flour and peptone on the yield of amylase when the soluble starch $(3.5 \% \mathrm{w} / \mathrm{v}), \mathrm{MgCl}_{2} .6 \mathrm{H}_{2} \mathrm{O}(0.015 \% \mathrm{w} / \mathrm{v})$ and $\mathrm{FeSO}_{4} \cdot 7 \mathrm{H}_{2} \mathrm{O}(6.0 \mathrm{ppm} \mathrm{w} / \mathrm{v})$ were held at zero level.

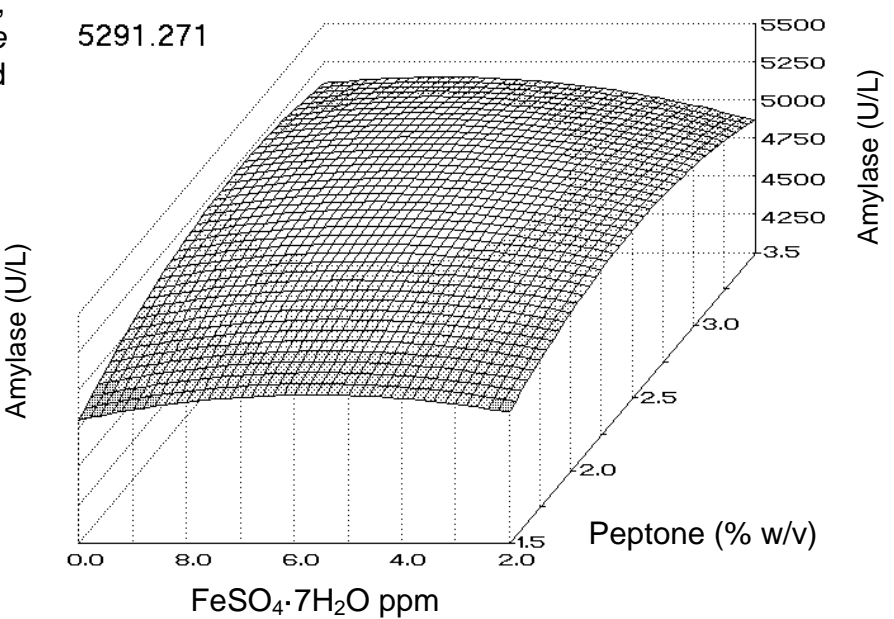

Figure 3a: Response surface plot for the production of thermostable amylopullulanase by $C$. thermosulfurogenes SVM17 in SmF as a function of varying concentrations of peptone and $\mathrm{FeSO}_{4} \cdot 7 \mathrm{H}_{2} \mathrm{O}$ on the yield of amylase when the soluble starch $(3.5 \% \mathrm{w} / \mathrm{v})$, tapioca flour $(3.5 \% \mathrm{w} / \mathrm{v})$ and $\mathrm{MgCl}_{2} \cdot 6 \mathrm{H}_{2} \mathrm{O}(0.015 \% \mathrm{w} / \mathrm{v})$ were held at zero level. 


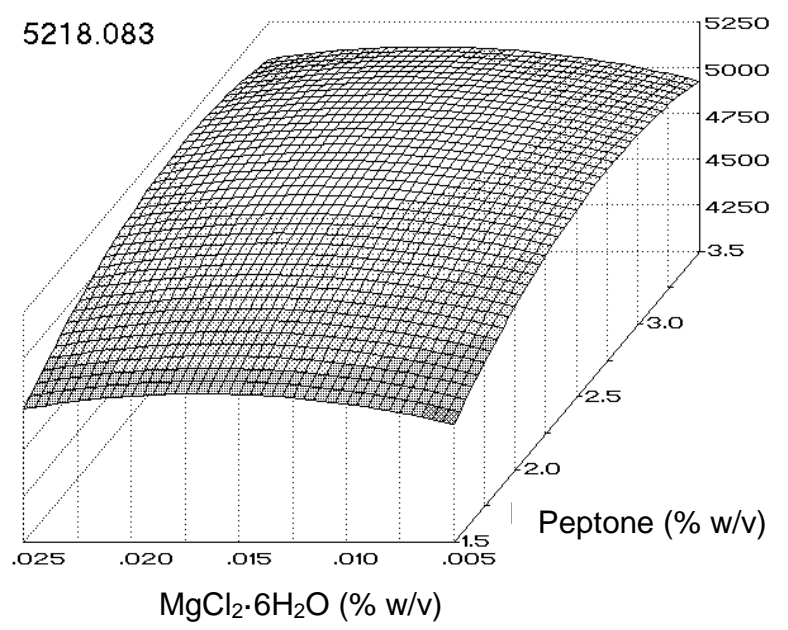

Figure 4a: Response surface plot for the production of thermostable amylopullulanaseby $C$. thermosulfurogenes SVM17 in SmF as a function of varying concentrations of peptone and $\mathrm{MgCl}_{2} \cdot 6 \mathrm{H}_{2} \mathrm{O}$ on the yield of amylase when the soluble starch $(3.5 \% \mathrm{w} / \mathrm{v})$, tapioca flour $(3.5 \% \mathrm{w} / \mathrm{v})$ and $\mathrm{FeSO}_{4} \cdot 7 \mathrm{H}_{2} \mathrm{O}(6.0 \mathrm{ppm} \mathrm{w/v})$ were held at zero level.

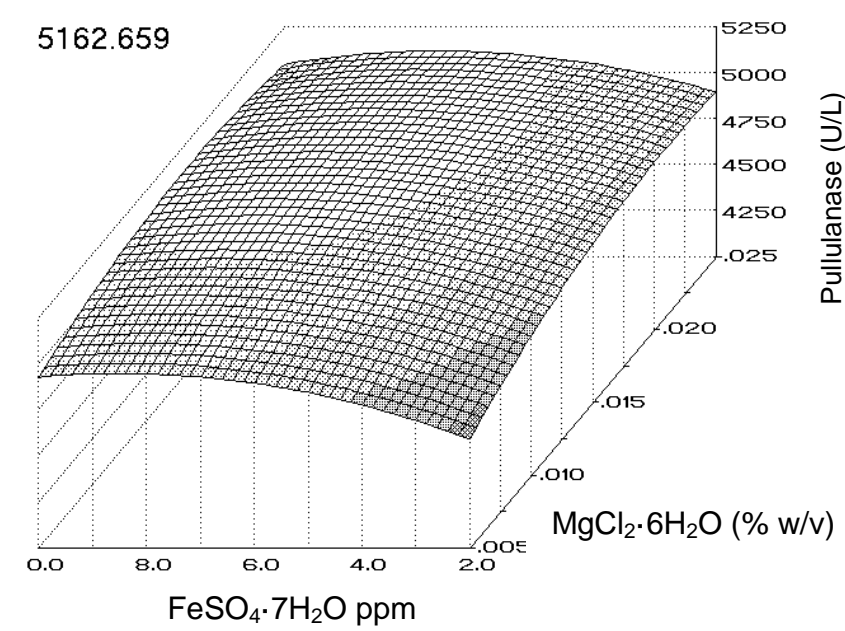

Figure 5a: Response surface plot for the production of thermostable amylopullulanase by $C$. thermosulfurogenes SVM17 in SmF as a function of varying concentrations of $\mathrm{MgCl}_{2} \cdot 6 \mathrm{H}_{2} \mathrm{O}$ and $\mathrm{FeSO}_{4} \cdot 7 \mathrm{H}_{2} \mathrm{O}$ on the yield of amylase when the soluble starch $(3.5 \% \mathrm{w} / \mathrm{v})$, tapioca flour $(3.5 \%$ $\mathrm{w} / \mathrm{v})$ and peptone $(2.5 \% \mathrm{w} / \mathrm{v})$ were held at zero level.

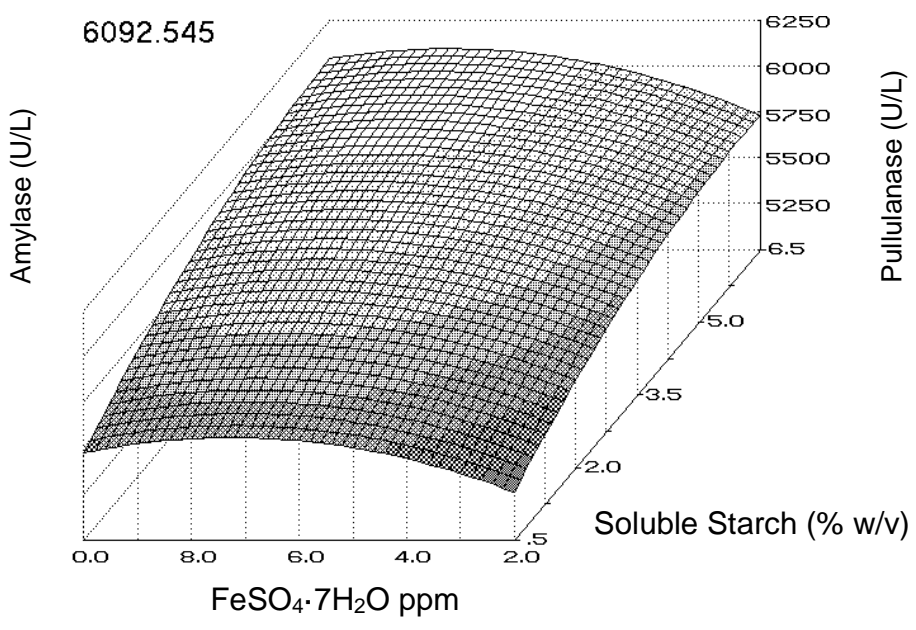

Figure 1b: Response surface plot for the production of thermostable amylopullulanase by $C$. thermosulfurogenes SVM 17 in $\mathrm{SmF}$ as a function of varying concentrations of soluble starch and $\mathrm{FeSO}_{4} \cdot 7 \mathrm{H}_{2} \mathrm{O}$ on the yield of pullulanase when the tapioca flour $(3.5 \% \mathrm{w} / \mathrm{v})$, peptone $(2.5 \% \mathrm{w} / \mathrm{v})$ and $\mathrm{MgCl}_{2} \cdot 6 \mathrm{H}_{2} \mathrm{O}(0.015 \% \mathrm{w} / \mathrm{v})$ were held at zero level.

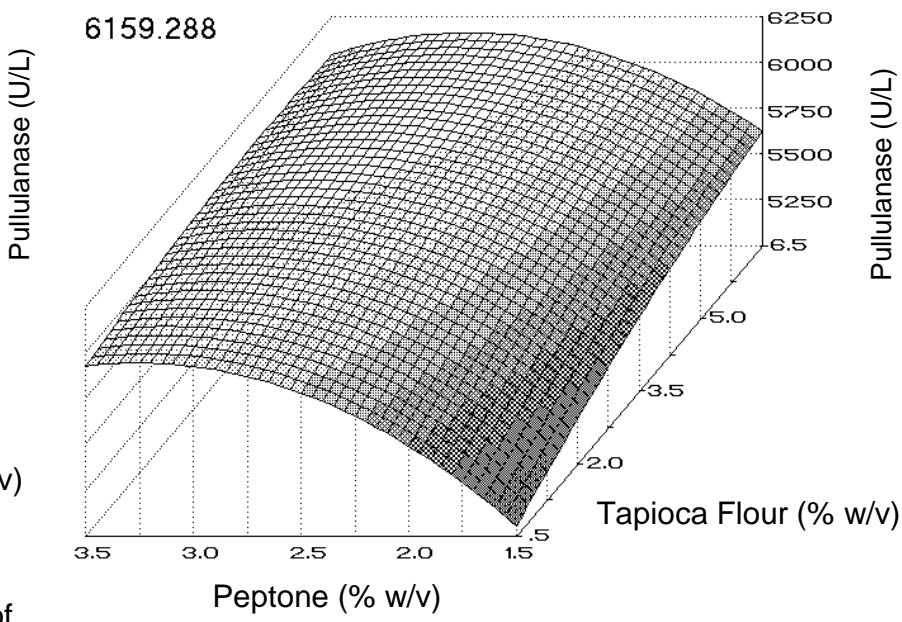

Figure 2b: Response surface plot for the production of thermostable amylopullulanase by $C$. thermosulfurogenes SVM 17 in SmF as a function of varying concentrations of tapioca flour and peptone on the yield of pullulanase when the soluble starch $(3.5 \% \mathrm{w} / \mathrm{v}), \mathrm{MgCl}_{2} \cdot 6 \mathrm{H}_{2} \mathrm{O}(0.015 \% \mathrm{w} / \mathrm{v})$ and $\mathrm{FeSO}_{4} \cdot 7 \mathrm{H}_{2} \mathrm{O}(6.0 \mathrm{ppm} \mathrm{w} / \mathrm{v})$ were held at zero level. 


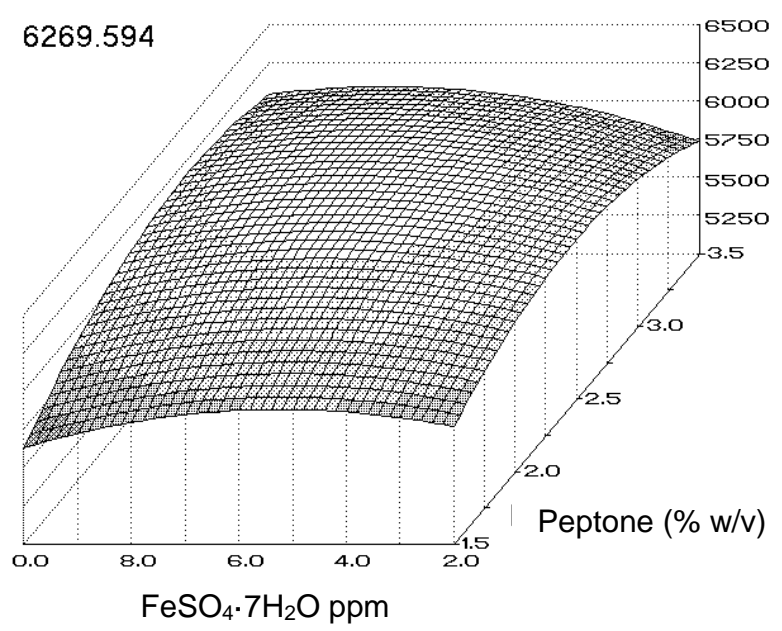

Figure 3b: Response surface plot for the production of thermostable amylopullulanase by $C$. thermosulfurogenes SVM17 in SmF as a function of varying concentrations of peptone and $\mathrm{FeSO}_{4} \cdot 7 \mathrm{H}_{2} \mathrm{O}$ on the yield of pullulanase when the soluble starch $(3.5 \% \mathrm{w} / \mathrm{v})$, tapioca flour $(3.5 \%$ $\mathrm{w} / \mathrm{v})$ and $\mathrm{MgCl}_{2} \cdot 6 \mathrm{H}_{2} \mathrm{O}(0.015 \% \mathrm{w} / \mathrm{v})$ were held at zero level.

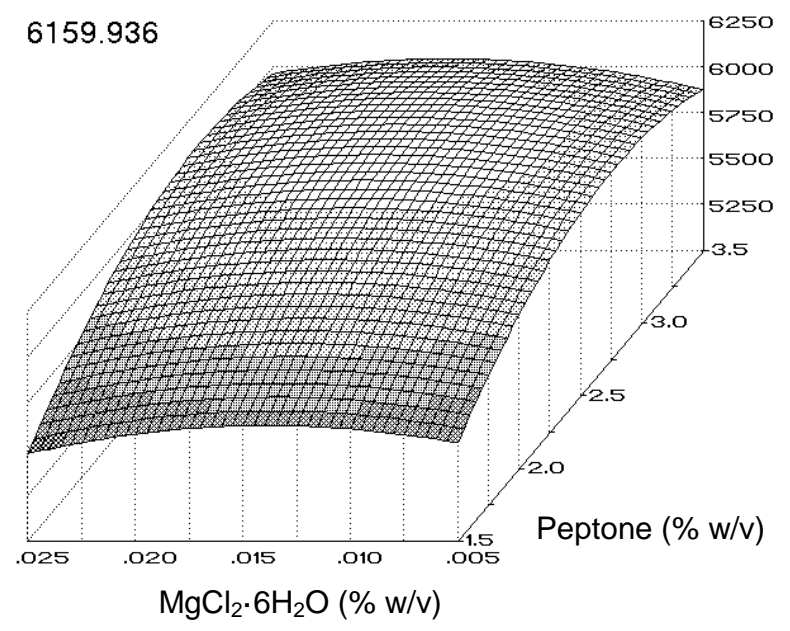

Figure 4b: Response surface plot for the production of thermostable amylopullulanase by $C$. thermosulfurogenes SVM17 in SmF as a function of varying concentrations of peptone and $\mathrm{MgCl}_{2} \cdot 6 \mathrm{H}_{2} \mathrm{O}$ on the yield of pullulanase when the soluble starch $(3.5 \% \mathrm{w} / \mathrm{v})$, tapioca flour $(3.5 \% \mathrm{w} / \mathrm{v})$ and $\mathrm{FeSO}_{4} \cdot 7 \mathrm{H}_{2} \mathrm{O}(6.0 \mathrm{ppm} \mathrm{w} / \mathrm{v})$ were held at zero level.

\section{CONCLUSIONS}

Conventional medium formulation studies are usually time consuming and expensive (Srinivas et al., 1994; Rama Mohan Reddy et al., 1999). To overcome these problems, an efficient fermentation medium for production of thermostable amylopullulanase with increased yields by C. thermosulfurogenes SVM17 has been developed. RSM was used to optimize the medium components. The optimized medium produced 96 and $409 \%$ more of

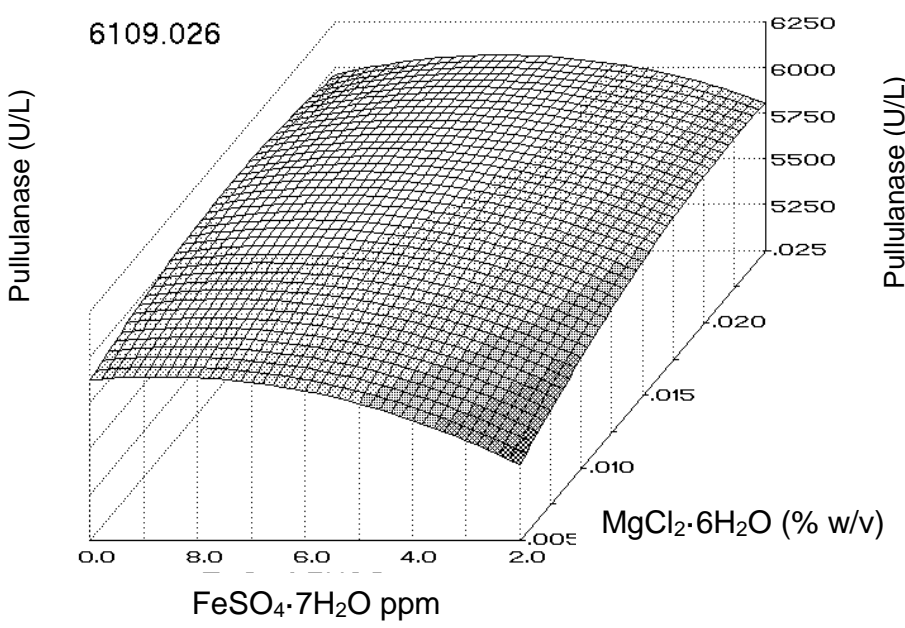

Figure 5b: Response surface plot for the production of thermostable amylopullulanase by $C$. thermosulfurogenes SVM17 in SmF as a function of varying concentrations of $\mathrm{MgCl}_{2} \cdot 6 \mathrm{H}_{2} \mathrm{O}$ and $\mathrm{FeSO}_{4} \cdot 7 \mathrm{H}_{2} \mathrm{O}$ on the yield of pullulanase when the soluble starch $(3.5 \% \mathrm{w} / \mathrm{v})$, tapioca flour $(3.5 \%$ $\mathrm{w} / \mathrm{v})$ and peptone $(2.5 \% \mathrm{w} / \mathrm{v})$ were held at zero level.

thermostable amylase and pullulanase, respectively which means that the productivity was greatly increased: The utilization of raw material with low cost, for example tapioca flour reduces overall cost of fermentation medium for amylopullulanase production therefore amylopullulanase production by $C$. thermosulfurogenes SVM17 can be considered as highly promising for industrial production than the un-optimized medium.

\section{ACKNOWLEDGEMENT}

The authors acknowledge Council of Scientific and Industrial Research (CSIR), New Delhi, India for providing funds. One of the authors (S. Mrudula) thanks the CSIR for award of senior research fellowship during the course of this investigation.

\section{REFERENCES}

Anonymous (1998). Indostat package is a software developed by Indostat services, Hyderabad, India for computing statistics. The present version of this package is 6.1 and it is being used in industry, agriculture and life sciences $R$ \&D.

Box, G. E. P. and Wilson, K. B. (1951). On the experimental attainment of optimum conditions. Journal of the Royal Statistical Society (Series B) 13, 1-45.

Burkert, J. F. M., Maugeri, F. and Rodrigues, M. I. (2004). Optimization of extra-cellular lipase production by Geotrichum sp. using factorial design. Bioresource Technology 91, 77-84. 
Cochran, W. G. and Cox G. M. (1957). Experimenta designs. $2^{\text {nd }}$ edn. John Wiley and Sons Ltd., New York.

Dey, G. S., Palit, S., Banerjee, R. and Maiti, B. R. (2002). Purification and characterization of maltooligosaccharide-forming amylase from Bacillus circulans GRS313. Journal of Industrial Microbiology and Biotechnology 28, 193-200.

Fogarty, W. M. and Kelly, C. T. (1990). Recent advances in microbial amylases. In: Microbial enzymes and Biotechnology. $2^{\text {nd }}$ edn. Fogarty, W. M. and Kelly, C. T. (eds.). Elsevier Applied Science Publishers, London. pp. 71-132.

Gong, X. and Chen, F. (1998). Influence of medium components on astaxanthin content and production of Haematococcus pluvialis. Process Biochemistry 33, 385-391.

Haki, G. D. and Rakshit, S. K. (2003). Developments in industrially important thermostable enzymes: A review. Bioresource Technology 89, 17-34.

Jagannadha Rao, K., Kim, C. H. and Rhee, S. K. (2000). Statistical optimization of medium for the production of recombinant hirudin from Saccharomyces cerevisiae using response surface methodology. Process Biochemistry 35,639-647.

Kapat, A., Jung, J. K., Park, Y. H., Hong, S. Y. and Choi, H. K. (1998). Effects of agitation and aeration on the production of extracellular glucose oxidase from a recombinant $S$. cerevisiae. Bioprocess Engineering 18, 347-351.

Khuri, A. I. and Cornell, J. A. (1987). Response Surfaces: Design and Analyses. Marcel Dekker Inc. NewYork. pp. 149-205.

Kwak, Y. S., Akiba, T. and Kudo, T. (1998). Purification and characterization of $\alpha$-amylase from hyperthermophilic archeon Thermococcus profoundus, which hydrolyses both $\alpha-1,4$ and $\alpha-1,6$ glucosidic linkages. Journal of Fermentation and Bioengineering 86, 363-367.

Lee, S. L. and Chen W. C. (1997). Optimization of medium composition for the production of glucosyltransferase by Aspergillus niger with response surface methodology. Enzyme Microbial Technology 21, 436-440.

Miller, G. L. (1959). Use of dinitrosalicylic acid reagent for determination of reducing sugars. Analytical Chemistry 31, 426-428.

Montgomery, D. C. (1991). Design and Analysis of Experiments. $3^{\text {rd }}$ edn. John Wiley and Sons, New York. pp. 540-541.

Mrudula, S. (2010). Optimisation of thermostable amylopullulanase production in solid state fermentation by Clostridium thermosulfurogenes SVM 17 through Plackett-Burmann and response surface methodological approaches. Malaysian Journal of Microbiology 6, 181-195.

Mrudula, S., Reddy, G. and Seenayya, G. (2010). Screening of medium components for production of thermostable amylopullulanase by Clostridium thermosulfurogenes SVM 17 in submerged fermentation using Plackett-Burman Design. Asian Journal of Microbiology, Biotechnology and Environmental Sciences 3, 4-9.

Mrudula, S., Gopal Reddy and Seenayya, G. (2011a). Effect of process parameters on production of thermostable amylopullulanase by Clostridium thermosulfurogenes SVM 17 under solid state fermentation. Malaysian Journal of Microbiology 6, 19-25

Mrudula, S., Gopal Reddy and Seenayya, G. (2011b). Extraction optimization of thermostable amylopullulanase from Clostridium thermosulfurogenes SVM 17 through solid state fermentation using RSM. International Journal of Biotechnology and Bioengineering Research 2, 29-44

Naidu, G. S. N. and Panda, T. (1999). Performance of pectolytic enzymes during hydrolysis of pectic substances under assay conditions: A statistical approach. Enzyme Microbial Technology 25, 116124.

Rama Mohan Reddy, P., Reddy, G. and Seenayya, G. (1999). Production of thermostable pullulanase by Clostridium thermosulfurogenes SV2 in solid state fermentation: Optimization of nutrients levels using response surface methodology. Bioprocess Engineering 21, 497-503.

Rama Mohan Reddy, P., Mrudula, S., Ramesh, B., Reddy, G. and Seenayya, G. (2000). Production of thermostable pullulanase by Clostridium thermosulfurogenes SV2 in solid state fermentation: optimization of enzyme leaching conditions using response surface methodology. Bioprocess Engineering 23, 107-112.

Rama Mohan Reddy, P., Ramesh, B., Mrudula, S., Reddy, G. and Seenayya, G. (2003). Production of thermostable $\quad \beta$-amylase $\quad$ Clostridium thermosulfurogenes SV2 in solid-state fermentation: Optimization of nutrient levels using response surface methodology. Process Biochemistry 39, 267-277.

Reddy, L. V. A., Wee, Y. J., Yun, J. S. and Won, H. (2008). Optimization of alkaline protease production by batch culture of Bacillus sp RKY3 through Plackett-Burman and response surface methodological approaches. Bioresource Technology 99, 2242-2249.

Saha, B. C. and Zeikus, J. G. (1989). Novel highly thermostable pullulanase from thermophiles. Trends in Biotechnology 7, 234-239.

Saha, B. C., Jordan, D. B. and Bothast, R. H. (2009). Enzymes Industrial (Overview): In: Encyclopedia of Microbiology. Schaechter, M. (ed.). Elsevier Ltd, Oxford. pp. 281-294.

Satyanarayana, T and Pradeep Kumar (2009). Microbial glucoamylases: characterstics and applications. Critical Reviews in Biotechnology 29, 225-255.

Spreinat, A. and Antranikian, G. (1990). Purification and properties of a thermostable pullulanase from Clostridium thermosulfurogenes EM1 which hydrolyses both $\alpha-1,6$ and $\alpha-1,4-$ glycosidic linkages. Applied Microbiology and Biotechnology 33, 511-518. 
Srinivas, M. R. S., Chand, N. and Lonsane, B. K. (1994). Use of Plackett-Burman design for rapid screening of several nitrogen sources, growth/product promoters, minerals and enzyme inducers for the production of alpha-galactosidase by Aspergillus niger MRSS 234 in solid state fermentation system. Bioprocess Engineering 10, 139-144.

Sunitha, K., Lee, J. K. and Oh, T. K. (1999). Optimization of medium components for phytase production by $E$. coli using response surface methodology. Bioprocess Engineering 21, 477-481.

Swamy, M. V. and Seenayya, G. (1996a). Clostridium thermosulfurogenes SV9. A thermophilic amylase producer. Indian Journal of Microbiology 36, 181-184.

Swamy, M. V. and Seenayya, G. (1996b). Thermostable pullulanase and $\alpha$-amylase activity from Clostridium thermosulfurogenes SV9-Optimization of culture conditions for enzymes production. Process Biochemistry 31, 157-162.

Tanyildizi, M. S., Ozer, D. and Elibol, M. (2005). Production of bacterial $\alpha$-amylase by $B$. amyloliquifaciens under solid substrate fermentation. Biochemical Engineering Journal 37, 294-297.

Teng, Y. and Xu, Y. (2008). Culture condition improvement for whole cell lipase production in submerged fermentation by Rhiozopus chinensis using statistical method. Bioresource Technology 99, 3900-3907.

Uma Maheswara Rao, J. L. and Satyanarayana, T. (2007). Improving production of hyper-thermostable and high maltose forming a-amylase by an extreme thermophile Geobacillus thermoleovorans using response surface methodology and its applications. Bioresource Technology 98, 345-352.

Vasconcelos, A. F., Vas, A. F. D., Barbosa, A. M., Robert, F. H. D., Scarminio, L. S. and Rezende, M. I. (2000). Optimization of laccase production by Botryosphaeria sp. in the presence of veratryl alcohol by the response-surface method. Process Biochemistry 35, 1131-1138.

Zareian, S., Khajeh, K., Ranjbar, B., Dabirmanesh, B., Ghollasi, M. and Mollania, N, (2010). Purification and characterization of a novel amylopullulanase that converts pullulan to glucose, maltose and maltotriose and starch to glucose and maltose. Enzyme and Microbial Technology 46, 57-63. 